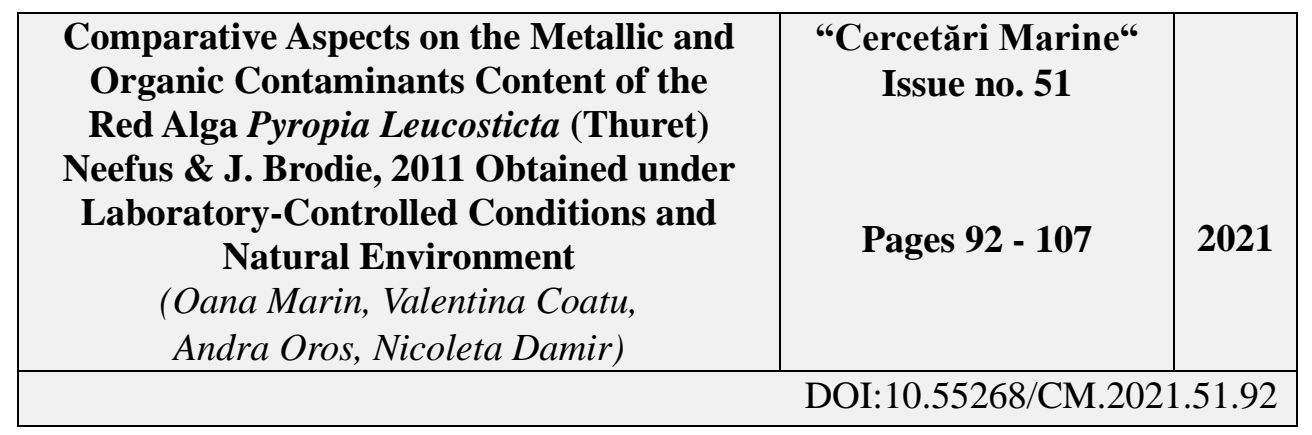

\title{
COMPARATIVE ASPECTS ON THE METALLIC AND ORGANIC CONTAMINANTS CONTENT OF THE RED ALGA Pyropia leucosticta (Thuret) Neefus \& J. Brodie, 2011 OBTAINED UNDER LABORATORY-CONTROLLED CONDITIONS AND NATURAL ENVIRONMENT
}

\author{
Oana Marin, Valentina Coatu, Andra Oros, Nicoleta Damir \\ National Institute for Marine Research and Development “Grigore Antipa”, \\ 300 Mamaia Blvd., 900581, Constanta, Romania \\ E-mail: omarin@alpha.rmri.ro
}

\begin{abstract}
Macroalgal cultures, a new domain for the Romanian Black Sea coast, provide interesting information on the intermediate stages of development and reproduction of algae, and also raw algal material with exploitable potential in most of diverse fields (industrial, cosmetic, pharmaceutical). Porphyra and Pyropia species are considered the world most valuable mariculture algal products. The aim of the paper was to present the comparative aspects regarding the chemical composition (heavy metals, lipids and organic contaminants, respectively, polycyclic aromatic hydrocarbons, organochlorine pesticides and polychlorinated biphenyls) of the specimens obtained in laboratory culture with those collected from the natural environment. The analyzed biological material consisted of $P$. leucosticta tissue harvested from both laboratory culture and natural environment. After 5 months of experimental culture, the obtained wet biomass was $44.23 \mathrm{~g}$, while the lyophilization dried biomass was $4.94 \mathrm{~g}$. In the specimens obtained through reproductive elements manipulation, under laboratory-controlled conditions, 7 organic compounds were detected, which represent a much smaller number compared with the 20 compounds detected in specimens collected from natural environment. Meanwhile, the presence of all chlorinated organic pollutants was identified in the algal material collected from natural environment. Also, the lipids content was higher in cultured organisms. Heavy metal concentrations (20.72

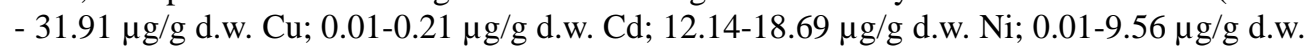
$\mathrm{Cr}$ ) were comparable with the ranges reported for various macroalgae species from Black Sea region.
\end{abstract}

Key-Words: macroalgae culture, chemical composition, organic contaminants, heavy metals 


\section{AIMS AND BACKGROUND}

Macrophytes cultures are a new domain for the Romanian Black Sea coast, providing interesting information on the intermediate stages of development and reproduction of macroalgae, aspects difficult to captured in natural environment. Macroalgal culture can provide raw algal material with exploitable potential in most diverse fields, without an exploitation and damage of natural resources. Globally, the macroalgal species that are suitable for intensive laboratory cultures are considered to be Laminaria, Porphyra, Undaria, Gracilaria, Chondrus, Ulva (Milchakova, 2011), but most of these species are not to be found along the Romanian Black Sea coast.

Porphyra ssp., also known under their commercial name of Nori, are considered worldwide as a high-valued mariculture algal product, due to their nutritional value and active principles. P. leucosticta is the only Nori representative for the Romanian Black Sea coast, with an exclusive development during cold season (is a stenothermic species), but without an abundant mass development in natural environment. P. leucosticta has a specific antioxidant activity (Mayalen et al., 2009), high vitamin C, carotenoids and chlorophyll $a$ content, high quality proteins, nitrogen, phosphorus, minerals, porphyrans (characteristic Porphyra species compounds) and antitumoral substances (Milchakova, 2011). Knowing the chemical composition of the laboratory culture specimens in comparison with those collected from the sea, is a particularly important aspect, necessary to be well known before any valorification procedure.

Heavy metals are natural constituents of the marine and freshwater environment, generally found in very low concentrations. Human activity (mine drainage, offshore oil and gas exploration, industrial and domestic effluents, agricultural runoff, etc.) has inevitably increased the levels of metal ions in many of these natural water systems. In their natural concentrations, some metals play an essential role in many biochemical processes in living organisms, but any concentration that exceeds the background, can become toxic (Laane, 1992; Ansari et al., 2004). Metals bioavailability is one of the determining factors of their accumulation in marine organisms. Metals uptake from seawater is influenced by metal speciation, chelating agents' presence, $\mathrm{pH}$, temperature, salinity, redox conditions (Alzieu, 1999). Metal uptake and elimination are determined by biological parameters that include external surfaces permeability, feeding strategies, types of internal ligands, efficiency of excretory systems, nutritional status, growth, season and reproductive stage (Depledge and Rainbow, 1990).

Among organic pollutants, pesticide residues, polychlorinated biphenyls and polycyclic aromatic hydrocarbons are encountered in the marine coastal environment. Polycyclic aromatic hydrocarbons may come into environment from anthropogenic or natural sources. Anthropic sources 
include the release into the environment of polycyclic aromatic hydrocarbons by incomplete combustion of carbon-containing materials (coal, oil, wood), by direct leakage of crude oil or refined petroleum products, by erosion of oilcontaminated materials in the aquatic environment (Kissao et al., 2011). Persistent organic pollutants such as polychlorinated biphenyls and organochlorine pesticides have caused deep concern due to their toxicity, persistence, bioaccumulation, high long-range atmospheric transport and potentially adverse health effects on marine organisms and humans (Kilunga et al., 2017). Despite their ban or restricted use, they are still found in various environmental matrices due to their low degradation (Syakti et al., 2013).

Most studies concerning the accumulation of contaminants in macroalgae involved inorganic contaminants (97\%) and very few involved organic contaminants (3\%). The main organic contaminants studied were PCBs, PAHs and DDT or DDT metabolites (García-Seoane et al., 2018).

The aim of the paper was to present the comparative aspects regarding the chemical composition (heavy metals, lipids and organic contaminants, respectively, polycyclic aromatic hydrocarbons, organochlorine pesticides and polychlorinated biphenyls) of the specimens obtained in laboratory culture with those collected from the natural environment.

\section{EXPERIMENTAL}

The experimental part started during the cold season, with field activities, in order to collect $P$. leucosticta mature reproductive thalli from depths of about 0.5 to 1 meter (natural rocky substrate) from Pescărie area (near Constanta city) (Fig. 1).

The main pollution sources in the area are considered to be the sewage treatment plant from Constanta Nord, but also the intense tourism activities during the summer season. Further, the biological material was brought to laboratory for processing, analysis and initiating the experiment.

The algal reproductive tissue was excised and stored for 24 hours in dark, cold $\left(4^{\circ} \mathrm{C}\right)$ conditions. Subsequently, the reproductive tissue was placed into Petri dishes, in sterile water, at $10-15^{\circ} \mathrm{C}$, under low light, to release the reproductive elements (spores). The spores were then collected and inoculated into sterile Petri dishes (with a microscope slide attached) and Von Stosch Enrichment Solution (VSE) culture medium - a mixture of filtered autoclaved seawater, with an addition of salts and vitamins. The nutrient medium was changed every 2 weeks to maintain a viable culture and to accelerate the development of the newly formed blades. The experimental culture was maintained between $10-15^{\circ} \mathrm{C}$, with a lighting regime of 12:12 (12 hours light: 12 hours dark) (Redmond et al., 2014), submitted to a daily monitoring for 5 months. Larger flasks (previously sterilized) were used according to blades newly dimensions (Marin et al, 2019). At the end of the experimental culture, 
the algal material was collected, weighed and prepared for chemical analysis.

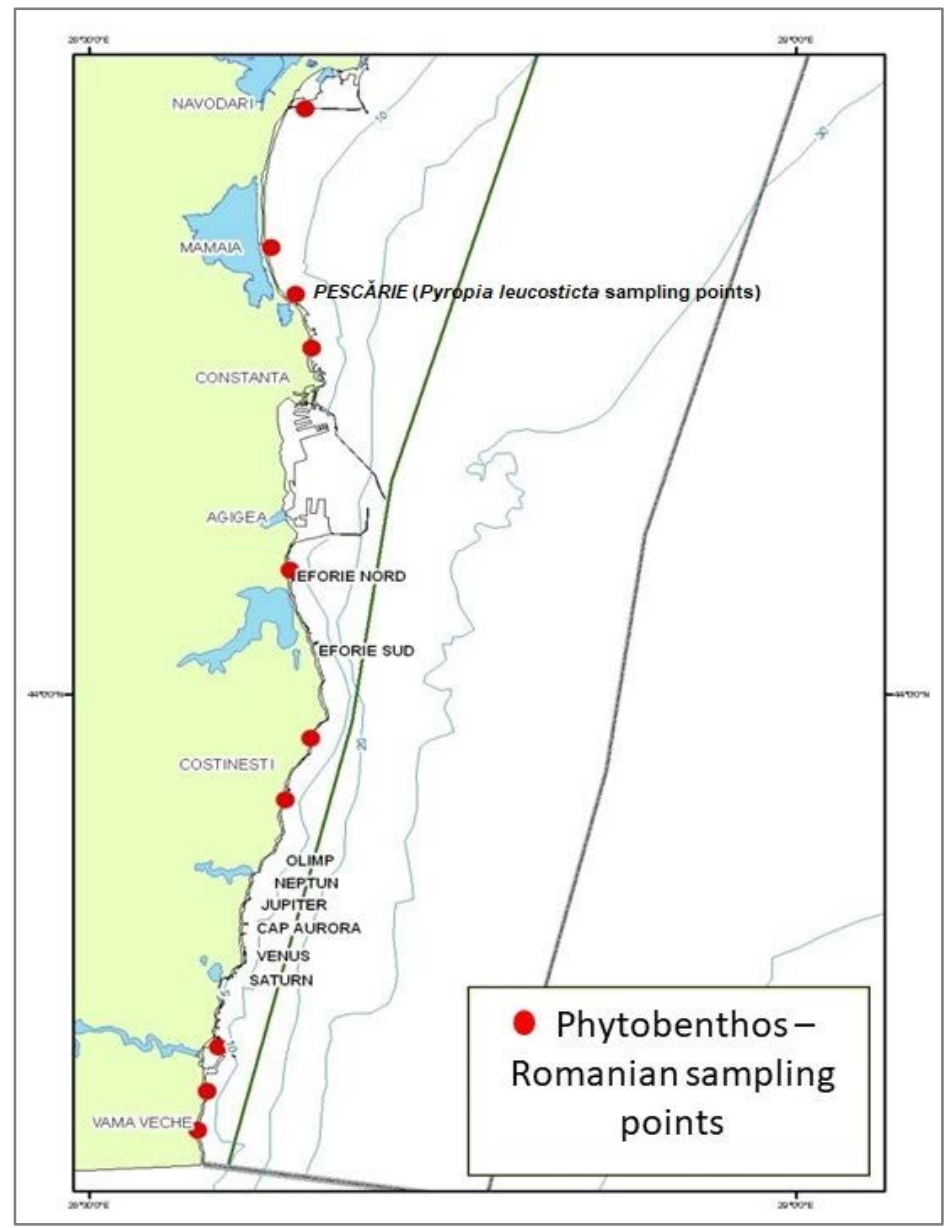

Fig. 1. P. leucosticta sampling points

Heavy metals ( $\mathrm{Cu}, \mathrm{Cd}, \mathrm{Pb}, \mathrm{Ni}, \mathrm{Cr}$ ) were determined after lyophilization and acid digestion (Ultrapure HNO3), through graphite furnace atomic absorption spectrometry (GFAAS), using a SOLAAR M6 Dual Thermo Electron equipment. Calibration was performed with working standards prepared for each element, starting from stock solutions of $1000 \mu \mathrm{g} / \mathrm{L}$ (Merck). The working ranges were: $\mathrm{Cu} 0-50 \mu \mathrm{g} / \mathrm{L}$; Cd 0-10 $\mu \mathrm{g} / \mathrm{L} ; \mathrm{Pb} 0-20 \mu \mathrm{g} / \mathrm{L}$; Ni 0$50 \mu \mathrm{g} / \mathrm{L}$; Cr 0-50 $\mu \mathrm{g} / \mathrm{L}$. Detection limits: $0.015 \mu \mathrm{g} / \mathrm{L} \mathrm{Cu}$; $0.0014 \mu \mathrm{g} / \mathrm{L} \mathrm{Cd}$; $0.007 \mu \mathrm{g} / \mathrm{L} \mathrm{Pb} ; 0.072 \mu \mathrm{g} / \mathrm{L} \mathrm{Ni} ; 0.0038 \mu \mathrm{g} / \mathrm{L}$ Cr. At least 3 readings were performed for each sample, the average value being reported.

For organic contaminants analysis, the biological material was dried through lyophilization and homogenized. The biological material consisted of $P$. leucosticta tissue collected from natural environment (Pescărie - Fig.1) and 
laboratory culture. Approximately 2 grams of dry tissue was used for the analysis of organochlorinated compounds (organochlorine pesticides, respectively HCB, lindane, heptachlor, aldrin, dieldrin, endrin, p,p' DDE, p,p' DDD, p,p' DDT and polychlorinated biphenyls, respectively PCB 28, PCB 52, PCB 101, PCB 118, PCB 153, PCB 138, PCB 180 ). No replicates were used, and a laboratory blank was analyzed following the same procedure as for the samples. For quantification of the global recovery of analytical procedures, internal standard 2,4,5-trichlorobiphenyl was added in samples. The extraction was performed with $30 \mathrm{ml}$ of acetone/hexane (1: 1, v: v) within Start E Milestone microwave extraction system, for 30 minutes, at $120^{\circ} \mathrm{C}$. Subsequent processing of samples consisted of purification on a florisil column and samples concentration using the Kuderna-Denish concentrator and nitrogen flow. Analytical determination of organochlorinated compounds content was performed by gas chromatographic method with a Perkin Elmer CLARUS 500 chromatograph, equipped with an electron capture detector. The extraction was performed with $30 \mathrm{ml}$ of acetone/hexane (1: 1, v: v) within Start E Milestone microwave extraction system, for 30 minutes, at $120^{\circ} \mathrm{C}$. Subsequent processing of samples consisted of purification on a florisil column and samples concentration using the Kuderna-Denish concentrator and nitrogen flow. Analytical determination of organochlorinated compounds content was performed by gas chromatographic method with a Perkin Elmer CLARUS 500 chromatograph, equipped with an electron capture detector. Detection limits for organochlorine pesticides were: $0.0005 \mu \mathrm{g} / \mathrm{g}$ HCB, 0.0004 $\mu \mathrm{g} / \mathrm{g}$ lindane, $0.0003 \mu \mathrm{g} / \mathrm{g}$ heptachlor, $0.0003 \mu \mathrm{g} / \mathrm{g}$ aldrin, $0.0004 \mu \mathrm{g} / \mathrm{g}$ dieldrin, $0.0004 \mu \mathrm{g} / \mathrm{g}$ endrin, $0.0002 \mu \mathrm{g} / \mathrm{g}$ p,p' DDE, $0.0002 \mu \mathrm{g} / \mathrm{g}$ p,p' DDD, $0.0002 \mu \mathrm{g} / \mathrm{g}$ p,p' DDT and for polychlorinated biphenyls: $0.0004 \mu \mathrm{g} / \mathrm{g}$ PCB 28, $0.0003 \mu \mathrm{g} / \mathrm{g}$ PCB 52, $0.0006 \mu \mathrm{g} / \mathrm{g}$ PCB 101, $0.0004 \mu \mathrm{g} / \mathrm{g}$ PCB 118, 0.0006 $\mu \mathrm{g} / \mathrm{g}$ PCB 153, $0.0007 \mu \mathrm{g} / \mathrm{g}$ PCB 138, $0.0003 \mu \mathrm{g} / \mathrm{g}$ PCB 180.

Approximately 2 grams of dry tissue were used for the analysis of polynuclear aromatic hydrocarbons, respectively naphtalene, acenaphtylene, acenapthene, fluorene, phenantrene, anthracene, pyrene, fluoranthene, benzo[a]anthracene, chrysene, benzo[b]fluoranthene, benzo[k]fluoranthene, benzo[a]pyrene, benzo(ghi)perylene, dibenzo[a,h]anthracene and indeno[1,2,3-cd] pyrene. No replicates were used, and a laboratory blank was analyzed following the same procedure as for the samples. For quantification of the global recovery of analytical procedures, internal standard 9.10 dihydroanthracene was added in samples. The extraction was performed with $250 \mathrm{ml}$ of methanol in the Soxhlet extractor for 8 hours. The extracts were then saponified by adding $20 \mathrm{ml}$ of $\mathrm{KOH} 0.7 \mathrm{M}$ and $30 \mathrm{ml}$ of distilled water and refluxed for 2 hours. The mixture was transferred to a separatory funnel and extracted 3 times with hexane. Samples processing followed the steps: extracts concentration on the rotary evaporator, alumina/silica gel column purification 
and concentration of samples using Kuderna-Denish concentrator and nitrogen flow. Analytical determination of polynuclear aromatic hydrocarbons content was performed by gas chromatographic method with a Perkin Elmer CLARUS 500 chromatograph, coupled with a mass spectrometer. Detection limit: $0.0001 \mu \mathrm{g} / \mathrm{g}$. Lipids extraction was performed with $30 \mathrm{ml}$ of solvent $(1: 1$ hexane/acetone) within microwave extraction system, for 50 minutes. The extracts were filtered through filter paper, obtaining clear filtrates, from which the lipids were determined by evaporation of the solvent and weighing.

\section{RESULTS AND DISCUSSION}

After 5 days of spores inoculation into Petri dishes, germinated spores and early stage development of new blades (with an initial division on a single plane), were observed. After 2 weeks, the newly formed blades started to divide into multiple planes (Fig. 2 a, b).

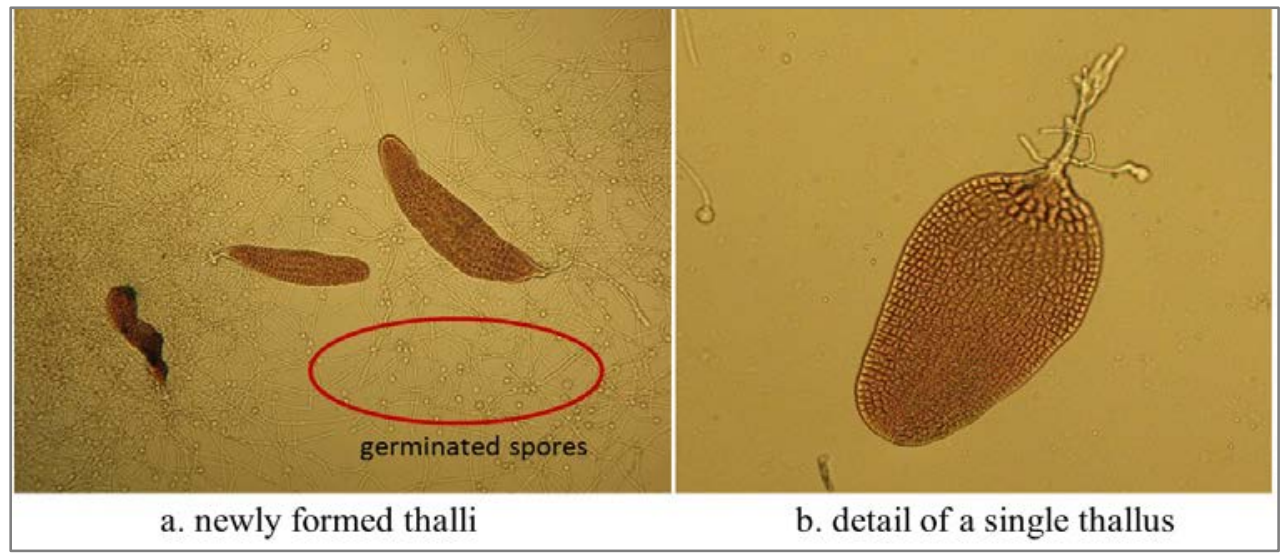

Fig. 2. P. leucosticta - microscopic aspects of newly formed thalli after 2 weeks of laboratory-controlled culture

After 2 weeks, a massive development of diatoms (Navicula sp.) was observed, yet a common problem for macroalgae laboratory cultures. To control this phenomenon, a germanium dioxide $\left(\mathrm{GeO}_{2}\right)$ treatment with was applied for 10 days (Redmond et al., 2014). Diatoms contamination slows down the growth of the new thalli, extremely sensitive in early stage of development. After 3-4 weeks, the new formed blades become macroscopically visible (with dimensions of approx. $0.2-0.4 \mathrm{~cm}$ ). After 5 weeks, an interesting phenomenon took place, namely a new spores release from the newly obtained blades in controlled culture. The spores were collected and introduced into culture vessels with an additional culture medium for a proper development. This is considered to be the 2nd generation of thalli, which became macroscopically visible after another 10 days. After 
6-7 weeks, algae dimensions vary between 0.2 and $1.5 \mathrm{~cm}$ (Fig. 3a). After 2 months, the culture was transferred to $250 / 500 \mathrm{ml}$ Erlenmeyer flasks with aeration system and 12:12 illumination regime (12 hours light: 12 hours darkness), proper conditions to accelerate the growth (Fig. 3b). Transfer to aquariums is not yet recommended, as sterile conditions are difficult to maintain at this stage.

Two days after the culture was transferred to larger flasks, the algae became reproductive and released new spores. These were carefully collected and inoculated into sterile Petri dishes, resuming the process presented above. After 3 months, the algae dimensions vary between 3 to $7 \mathrm{~cm}$. Towards the end of the experiment, namely after 5 months, the blades reached maximum dimensions of $8 \mathrm{~cm}$ (Fig. 4a). The algal material was collected, weighed (to determine the wet biomass), then dried by lyophilization and weighed again (to determine the dry biomass) (Fig. 4b).

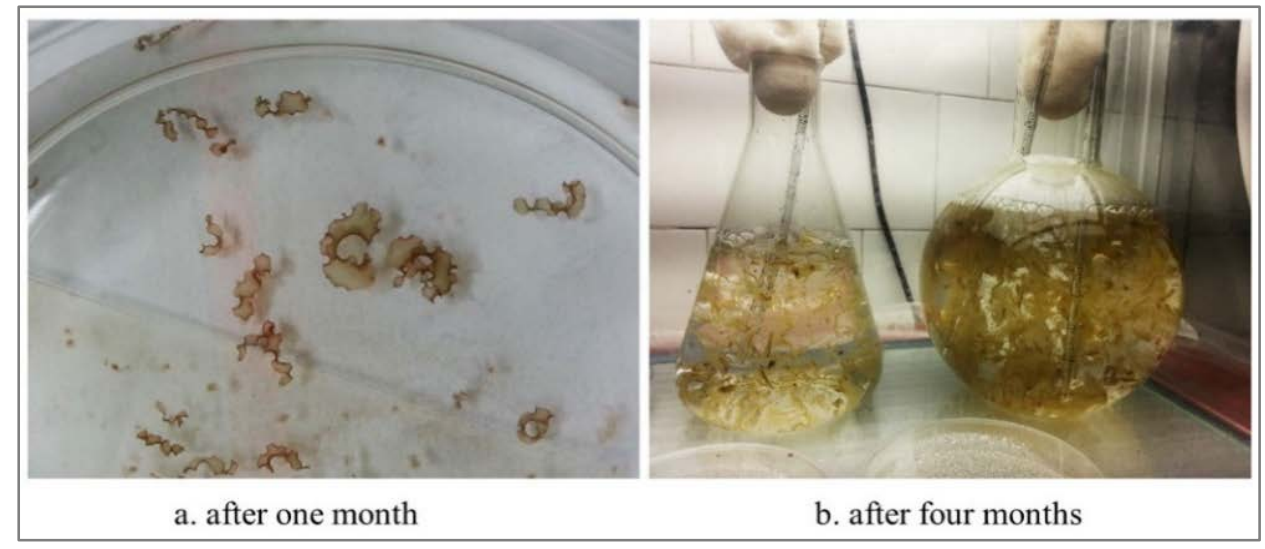

Fig. 3. P. leucosticta - macroscopic aspects of newly formed thalli

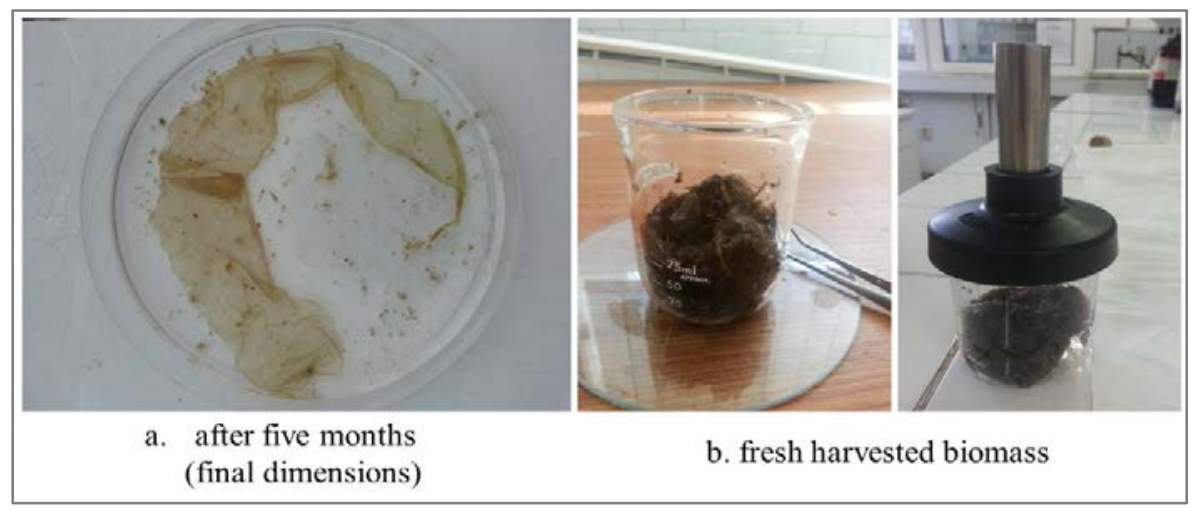

Fig. 4. P. leucosticta - final aspect after 5 months of experimental culture 
After 5 months of experimental culture, the obtained wet biomass was $44.23 \mathrm{~g}$, and the lyophilization dried biomass was $4.94 \mathrm{~g}$. Additional, a fresh biomass of $61.33 \mathrm{~g}$ was collected from natural environment, which was subsequently lyophilized, resulting a dry biomass of $4.56 \mathrm{~g}$. A series of chemical analyses were also performed on algal material harvested from the sea, in order to make comparative analyses between the algae from natural environment and those in culture (composite samples prepared from environmental algae and laboratory culture). The dried biomass (both in culture and natural environment) was subjected to chemical analyses.

The concentration of heavy metals determined in P. leucosticta samples collected from natural environment decreased as follows: $\mathrm{Cu}>\mathrm{Ni}>$ $\mathrm{Cd}>\mathrm{Pb}$, Cr. For laboratory-controlled conditions samples, the order was: $\mathrm{Cu}>$

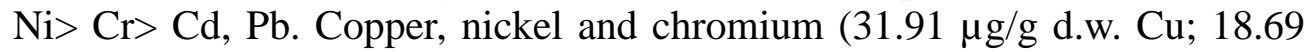
$\mu \mathrm{g} / \mathrm{g}$ d.w. Ni; $9.56 \mu \mathrm{g} / \mathrm{g}$ d.w. $\mathrm{Cr}$ ) had higher concentrations in laboratory culture samples. No information about heavy metals levels in seawater from sampling location is available, in order to make a comparison and give a possible explanation for higher levels in culture algae.

Although, it should be noted that metals such as copper, nickel, and chromium are essential nutrients that are required for various biochemical and physiological functions in plants and animals (Tchounwou et al., 2012).

The situation is different for non-essential metals, like cadmium and lead. While cadmium showed higher concentrations $(0.21 \mu \mathrm{g} / \mathrm{g}$ d.w. Cd) in specimens harvested from natural environment, extremely diminished values of lead were observed $(<0.01 \mu \mathrm{g} / \mathrm{g}$ d.w. $\mathrm{Pb})$, both in natural environment and laboratory culture specimens (Fig. 5; Fig. 6).

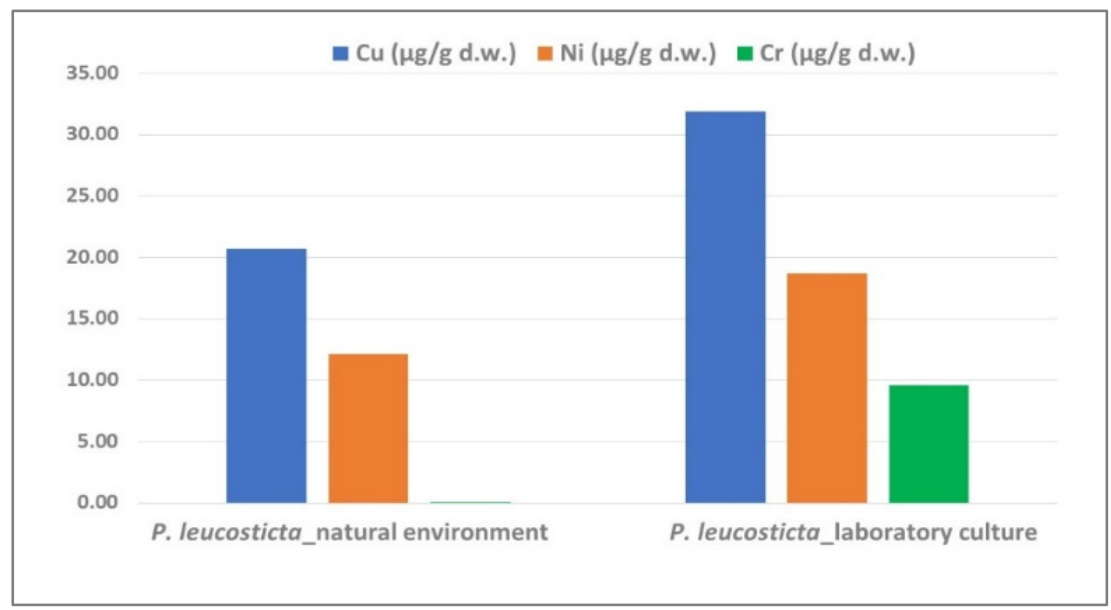

Fig. 5. Comparative analysis of copper, nickel and chromium concentrations in P. leucosticta samples from natural environment and culture 


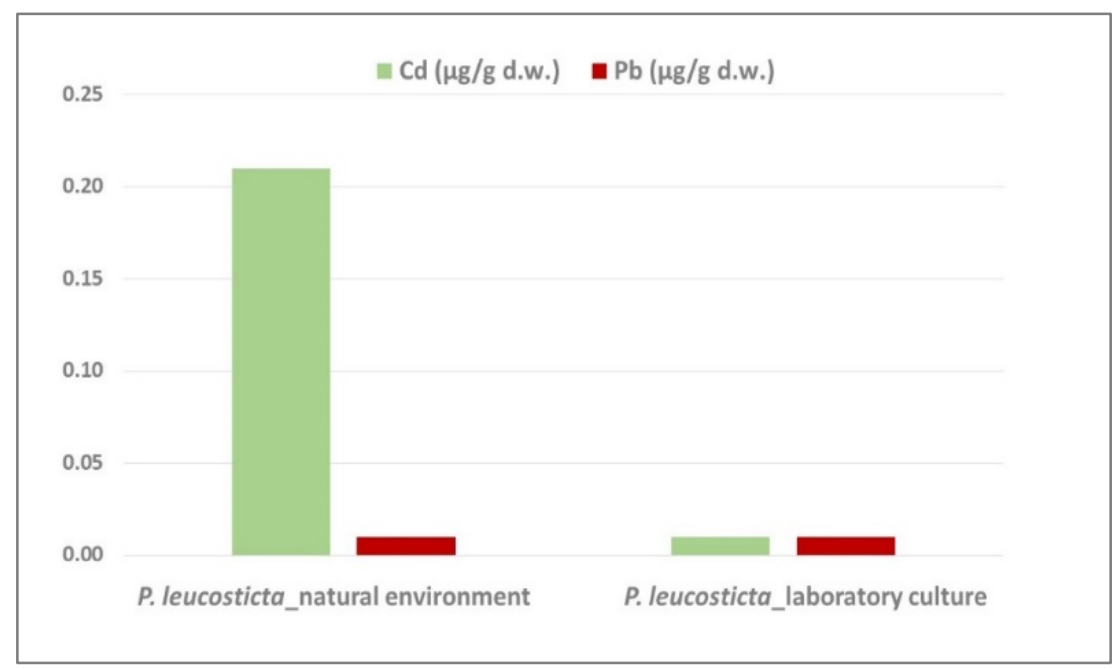

Fig. 6. Comparative analysis of cadmium and lead concentrations In $P$. leucosticta samples from natural environment and culture

Heavy metals concentrations measured in algal material collected from natural environment (20.72 - $31.91 \mu \mathrm{g} / \mathrm{g}$ d.w. Cu; 0.01-0.21 $\mu \mathrm{g} / \mathrm{g}$ d.w. Cd; 12.14-18.69 $\mu \mathrm{g} / \mathrm{g}$ d.w. Ni; 0.01-9.56 $\mu \mathrm{g} / \mathrm{g}$ d.w. Cr) are comparable with the ranges reported in previous studies (2011-2018) for the Romanian Black Sea coast. In addition, the values are similar to the data reported for macrophyte species from other Black Sea areas (Bat, 2014). It is noted that lead showed in this study case much lower values $(<0.01 \mu \mathrm{g} / \mathrm{g}$ d.w. $\mathrm{Pb})$, both in algal material harvested from natural environment and laboratory culture, in comparison to previous similar studies (Table 1).

In samples collected from natural environment, the presence of all persistent organic contaminants analyzed was noticed, respectively organochlorine pesticides and polychlorinated biphenyls. From polynuclear aromatic hydrocarbons, fluorene, phenanthrene, anthracene and dibenzo (a, h) anthracene were identified. The algae from laboratory-controlled culture contained a much smaller number of investigated compounds comparing to algae harvested from natural environment. Four organochlorine pesticides, namely lindane, heptachlor, p' DDE and p,p’ DDD were identified and no polychlorinated biphenyls. From the group of polynuclear aromatic hydrocarbons, about the same compounds as in algae harvested from the sea (phenanthrene, anthracene and dibenzo $(\mathrm{a}, \mathrm{h})$ anthracene) were observed. The lipids content was higher in algae obtained under laboratory-controlled conditions (Table 2).

The chlorinated compounds concentrations were higher for both polychlorinated biphenyls (Fig. 7) and organochlorine pesticides (Fig. 8) in 
algae harvested from natural environment, most probably as a result of the uptake from the environment.

Monitoring data (Boicenco et al., 2018) often evidence the presence of chlorinated compounds in coastal area, sometimes in concentrations exceeding the threshold values corresponding to good ecological status.

Regarding polynuclear aromatic hydrocarbons, for some of the compounds, namely phenanthrene and anthracene, the concentrations were much higher in algae obtained under laboratory culture comparing to those collected from natural environment (Fig. 9).

Table 1. Heavy metals concent rations in P. leucosticta compared to previous analyses (2011-2018) and data reported for other macroalgae species in Black Sea region

\begin{tabular}{|c|c|c|c|c|c|c|c|}
\hline $\begin{array}{l}\text { Analysed } \\
\text { group }\end{array}$ & $\begin{array}{l}\text { Sampling } \\
\text { area }\end{array}$ & $\begin{array}{c}\text { Cu } \\
(\mu g / g \\
\text { d.w. })\end{array}$ & $\begin{array}{l}\text { Cd } \\
(\mu g / g \\
\text { d.w. })\end{array}$ & $\begin{array}{c}\text { Pb } \\
(\mu g / g \\
\text { d.w. })\end{array}$ & $\begin{array}{c}\mathrm{Ni} \\
(\mu \mathrm{g} / \mathrm{g} \\
\text { d.w. })\end{array}$ & $\begin{array}{c}\text { Cr } \\
(\mu g / g \\
\text { d.w. })\end{array}$ & References \\
\hline $\begin{array}{l}\text { Red algae } \\
\text { P.leucosticta }\end{array}$ & $\begin{array}{l}\text { Black } \\
\text { Sea_RO }\end{array}$ & $\begin{array}{c}20.72 \\
- \\
31.91\end{array}$ & $\begin{array}{c}0.01 \\
- \\
0.21\end{array}$ & $<0.01$ & $\begin{array}{c}12.14 \\
- \\
18.69\end{array}$ & $\begin{array}{c}0.01 \\
- \\
9.56\end{array}$ & $\begin{array}{l}\text { Current } \\
\text { analyses }\end{array}$ \\
\hline $\begin{array}{l}\text { Red algae } \\
\text { Ceramium } \\
\text { ssp. }\end{array}$ & $\begin{array}{c}\text { Black } \\
\text { Sea_RO }\end{array}$ & $\begin{array}{c}13.41 \\
- \\
20.77\end{array}$ & $\begin{array}{c}0.13 \\
- \\
0.46\end{array}$ & $\begin{array}{c}1.28 \\
- \\
9.48\end{array}$ & $\begin{array}{c}10.97 \\
- \\
18.44\end{array}$ & $\begin{array}{c}1.85 \\
- \\
9.81\end{array}$ & $\begin{array}{l}\text { Oros, 2011- } \\
\text { 2016, } \\
\text { unpublished } \\
\text { data } \\
\end{array}$ \\
\hline $\begin{array}{l}\text { Red algae } \\
\text { Ceramium } \\
\text { ssp. }\end{array}$ & $\begin{array}{l}\text { Black } \\
\text { Sea_TR }\end{array}$ & $\begin{array}{c}2.65 \\
- \\
20.03\end{array}$ & $\begin{array}{c}0.05 \\
- \\
1.62\end{array}$ & $\begin{array}{c}0.01 \\
- \\
10.80\end{array}$ & $\begin{array}{c}0.28 \\
- \\
11.20\end{array}$ & & Bat, 2014 \\
\hline $\begin{array}{l}\text { Brown } \\
\text { algae } \\
\text { Cystoseira } \\
\text { ssp. }\end{array}$ & $\begin{array}{c}\text { Black } \\
\text { Sea_RO }\end{array}$ & $\begin{array}{c}5.09 \\
- \\
12.47\end{array}$ & $\begin{array}{c}0.27 \\
- \\
0.93\end{array}$ & $\begin{array}{c}2.09 \\
- \\
18.29\end{array}$ & $\begin{array}{c}5.69 \\
- \\
10.03\end{array}$ & $\begin{array}{c}1.10 \\
- \\
2.84\end{array}$ & $\begin{array}{c}\text { Oros, } 2011 \\
\text { unpublished } \\
\text { data }\end{array}$ \\
\hline $\begin{array}{c}\text { Brown } \\
\text { algae } \\
\text { Cystoseira } \\
\text { ssp. }\end{array}$ & $\begin{array}{l}\text { Black } \\
\text { Sea_TR }\end{array}$ & $\begin{array}{c}1.70 \\
- \\
16.40\end{array}$ & $\begin{array}{c}0.02 \\
- \\
1.03\end{array}$ & $\begin{array}{c}0.01 \\
- \\
14.10\end{array}$ & $\begin{array}{c}0.79 \\
- \\
10.35\end{array}$ & & Bat, 2014 \\
\hline $\begin{array}{c}\text { Green algae } \\
\text { Cladophora } \\
\text { ssp., Ulva } \\
\text { ssp. } \\
\end{array}$ & $\begin{array}{c}\text { Black } \\
\text { Sea_RO }\end{array}$ & $\begin{array}{c}7.92 \\
- \\
33.57\end{array}$ & $\begin{array}{c}0.30 \\
- \\
1.74\end{array}$ & $\begin{array}{c}0.01 \\
- \\
13.51\end{array}$ & $\begin{array}{c}4.05 \\
- \\
24.37\end{array}$ & $\begin{array}{c}1.06 \\
- \\
22.06\end{array}$ & $\begin{array}{l}\text { Oros, 2011- } \\
\text { 2018, } \\
\text { unpublished } \\
\text { data } \\
\end{array}$ \\
\hline $\begin{array}{l}\text { Green algae } \\
\text { Ulva ssp. }\end{array}$ & $\begin{array}{l}\text { Black } \\
\text { Sea_TR }\end{array}$ & $\begin{array}{c}2.09 \\
- \\
24.10\end{array}$ & $\begin{array}{c}0.02 \\
- \\
3.30\end{array}$ & $\begin{array}{c}0.01 \\
- \\
9.30\end{array}$ & $\begin{array}{c}0.10 \\
- \\
31.50\end{array}$ & & Bat, 2014 \\
\hline
\end{tabular}

* Black Sea_RO - Romanian Black Sea coast; Black Sea_TR - Turkish Black Sea coast 
Table 2. Concentrations of organic contaminants and lipids in P. leucosticta harvested from natural environment and laboratory culture

\begin{tabular}{|c|c|c|c|c|c|c|}
\hline \multirow{3}{*}{ Compounds } & \multicolumn{6}{|c|}{ Pyropia leucosticta } \\
\hline & 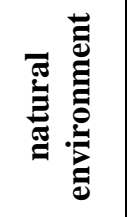 & 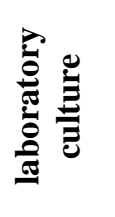 & 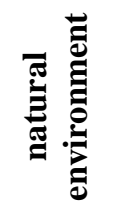 & 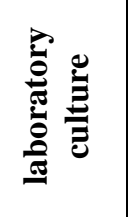 & 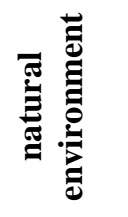 & 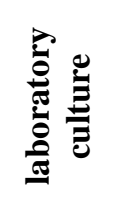 \\
\hline & \multicolumn{2}{|c|}{ ( $\mu \mathrm{g} / \mathrm{g}$ dry tissue) } & \multicolumn{2}{|c|}{ ( $\mu \mathrm{g} / \mathrm{g}$ wet tissue) } & \multicolumn{2}{|c|}{ ( $\mu$ g/g lipids) } \\
\hline \multicolumn{7}{|c|}{ Polychlorinated biphenyls } \\
\hline PCB28 & 0.78 & nd & 0.0580 & nd & 0.8667 & nd \\
\hline PCB52 & 0.07 & nd & 0.0052 & nd & 0.0778 & nd \\
\hline PCB101 & 0.22 & nd & 0.0164 & nd & 0.2444 & nd \\
\hline PCB118 & 0.64 & nd & 0.0476 & nd & 0.7111 & nd \\
\hline PCB153 & 0.08 & nd & 0.0059 & nd & 0.0889 & nd \\
\hline PCB138 & 1.01 & nd & 0.0751 & nd & 1.1222 & nd \\
\hline PCB180 & 0.04 & nd & 0.0030 & nd & 0.0444 & nd \\
\hline \multicolumn{7}{|c|}{ Organochlorine pesticides } \\
\hline HCB & 1.28 & nd & 0.0952 & nd & 1.4222 & nd \\
\hline Lindane & 0.22 & 0.19 & 0.0164 & 0.0212 & 0.2444 & 0.0109 \\
\hline Heptachlor & 0.12 & 0.01 & 0.0089 & 0.0011 & 0.1333 & 0.0006 \\
\hline Aldrin & 0.02 & nd & 0.0015 & nd & 0.0222 & nd \\
\hline p,p'DDE & 0.08 & 0.01 & 0.0059 & 0.0011 & 0.0889 & 0.0006 \\
\hline Dieldrin & 0.02 & nd & 0.0015 & nd & 0.0222 & nd \\
\hline Endrin & 0.01 & nd & 0.0007 & nd & 0.0111 & nd \\
\hline p,p'DDD & 0.01 & 0.07 & 0.0007 & 0.0078 & 0.0111 & 0.0040 \\
\hline p,p'DDT & 0.03 & nd & 0.0022 & nd & 0.0333 & nd \\
\hline \multicolumn{7}{|c|}{ Polynuclear aromatic hydrocarbons } \\
\hline Naphthalene & nd & nd & nd & nd & nd & nd \\
\hline Acenaphthylene & nd & nd & nd & nd & nd & nd \\
\hline Acenaphthene & nd & nd & nd & nd & nd & nd \\
\hline Fluorene & 0.24 & nd & 0.0178 & nd & 0.2667 & nd \\
\hline Phenanthrene & 0.18 & 0.92 & 0.0134 & 0.1028 & 0.2000 & 0.0529 \\
\hline Anthracene & 0.14 & 0.51 & 0.0104 & 0.0570 & 0.1556 & 0.0293 \\
\hline Fluoranthene & nd & nd & nd & nd & nd & nd \\
\hline Pyrene & nd & nd & nd & nd & nd & nd \\
\hline Benzo[a]anthracene & nd & nd & nd & nd & nd & nd \\
\hline Crysene & nd & nd & nd & nd & nd & nd \\
\hline Benzo[b]fluoranthene & nd & nd & nd & nd & nd & nd \\
\hline Benzo[k]fluoranthene & nd & nd & nd & nd & nd & nd \\
\hline Benzo[a]pyren & nd & nd & nd & nd & nd & nd \\
\hline
\end{tabular}




\begin{tabular}{|c|c|c|c|c|c|c|}
\hline \multirow{3}{*}{ Compounds } & \multicolumn{6}{|c|}{ Pyropia leucosticta } \\
\hline & 苞 & 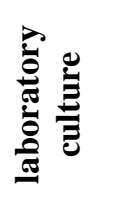 & 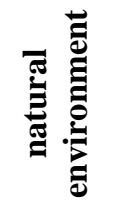 & 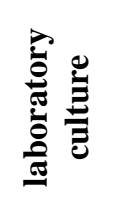 & 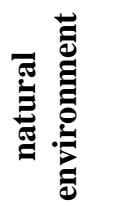 & 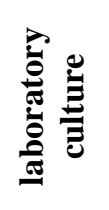 \\
\hline & \multicolumn{2}{|c|}{ ( $\mu \mathrm{g} / \mathrm{g}$ dry tissue) } & \multicolumn{2}{|c|}{ ( $\mu \mathrm{g} / \mathrm{g}$ wet tissue) } & \multicolumn{2}{|c|}{ ( $\mu$ g/g lipids) } \\
\hline Benzo (g,h,i) perylene & nd & nd & nd & nd & nd & nd \\
\hline Dibenzo (a,h) anthracene & 0.07 & 0.12 & 0.0052 & 0.0134 & 0.0778 & 0.0069 \\
\hline Indeno $(1,2,3-c, d)$ pyrene & nd & nd & nd & nd & nd & nd \\
\hline \multicolumn{7}{|l|}{ Lipids } \\
\hline Lipids & 0.9 & 17.4 & 0.067 & 1.944 & & \\
\hline
\end{tabular}

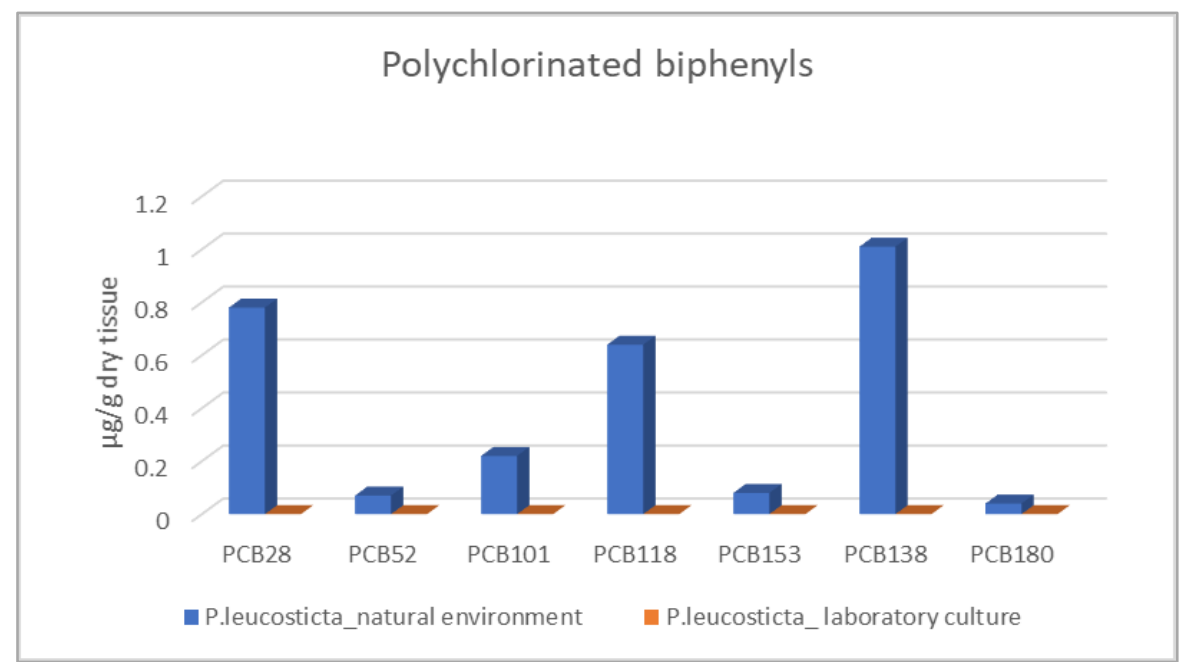

Fig. 7. Concentrations of polychlorinated biphenyls in P. leucosticta harvested from natural environment and laboratory culture

These petrogenic PAHs are common due to the widespread transportation, storage, and use of crude oil and crude oil products. Most probably, the source of this contamination is atmospheric releases of gasoline, motor oil, and related substances associated with transportation (Abdel-Shafy and Mansour, 2016).

In general, few contaminants have been found in laboratory culture specimens comparing to those collected from the sea (Fig. 10). In the specimens obtained through reproductive elements manipulation, under laboratory-controlled conditions, 7 organic compounds were detected, while in specimens collected from natural environment were detected 20 
compounds. Actually, all chlorinated organic pollutants were identified in the algal material collected from natural environment.

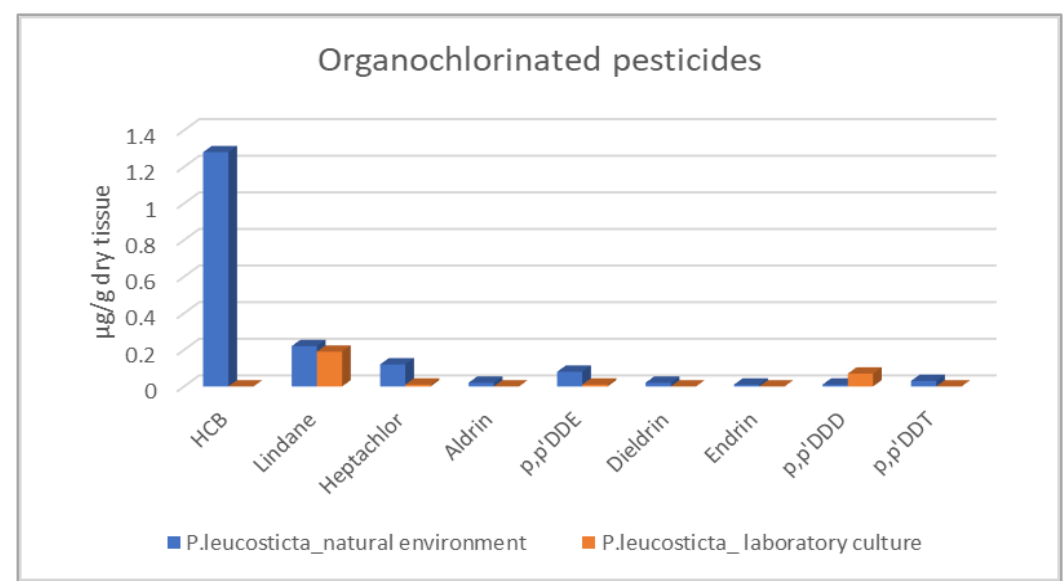

Fig. 8. Concentrations of organochlorine pesticides in P. leucosticta harvested from natural environment and laboratory culture

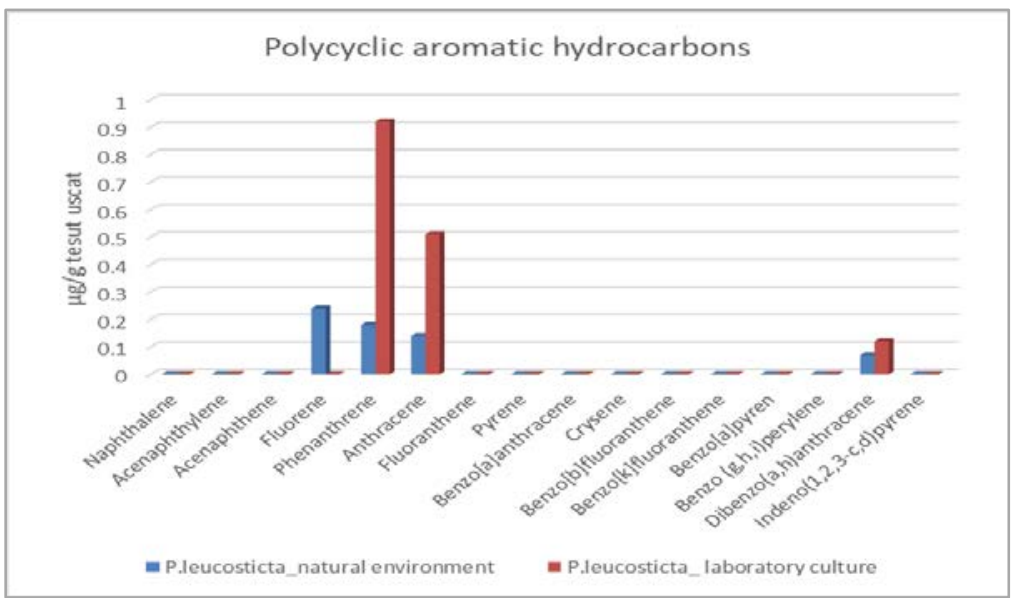

Fig. 9. Concentrations of polynuclear aromatic hydrocarbons in $P$. leucosticta harvested from natural environment and laboratory culture

Comparing the results obtained for P. leucosticta collected form the Romanian Black Sea coast with those obtained for the same species collected from the Venetian lagoon, it can be said that the concentrations of organic contaminants are much higher along the Romanian coast (Pavoni et al., 2003).

But, generally speaking, contaminants concentrations significantly depend on the age and/or condition of the algal mass (Maroli et al., 1993). Further studies will consider these factors. 


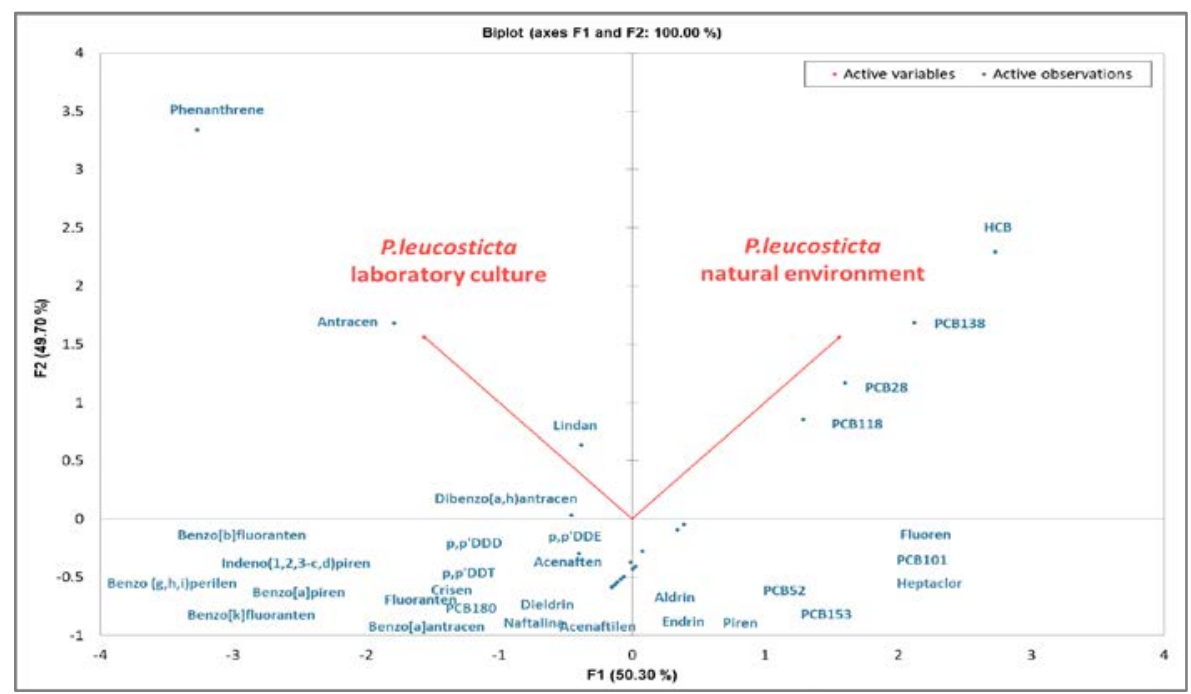

Fig. 10. P. leucosticta - organic contaminants analysis (natural environment and laboratory culture)

\section{CONCLUSIONS}

The reduced wet biomass (44.23 g) was due to the fact that this was only a small-scale experiment performed for educational purposes and not for obtaining a high biomass for further capitalization. So, taking into consideration these aspects, the red alga P. leucosticta can be considered suitable for cultivation under laboratory-controlled conditions, due to its high reproductive capacity and accelerated growth rate. The temperature range proved to be extremely important, since a temperature above $18^{\circ} \mathrm{C}$ was a limitation factor and greatly reduces the blades growth. At the end of the experiment, the newly formed thalli reached a maximum dimension of $8 \mathrm{~cm}$. After 5 months of experimental culture, the obtained fresh biomass was 44.23 $\mathrm{g}$, equivalent to a dry biomass of $4.94 \mathrm{~g}$.

Heavy metals concentration was in normal ranges, similar to previous analyses for other macroalgae species along the Romanian Black Sea coast. The observed variations may be due to interspecific differences in selectivity for certain metals and also to natural environment fluctuations. Further studies involving sampling and analyses in different areas and seasons to highlight these variations that may be related to both natural and human factors are recommended. Decreased lead concentrations were recorded in P. leucosticta both from natural environment and laboratory culture.

Among polynuclear aromatic hydrocarbons, fluorene, phenanthrene, anthracene and dibenzo $(\mathrm{a}, \mathrm{h})$ anthracene were identified both in natural and laboratory culture samples. Regarding the chlorinated compounds, the concentrations were higher in algae sampled from natural environment comparing to laboratory culture samples, both for organochlorine pesticides 
and polychlorinated biphenyls. Laboratory cultured specimens presented a lower number of detected compounds and a higher lipids content comparing to natural environment algal material.

Acknowledgement. The study has been supported by NUCLEU Program (INTELMAR), funded by the Ministry of Research, Innovation and Digitization, financing contract no. 45N/14.02.2019, project PN19260202.

\section{REFERENCES}

Abdel-Shafy H. I., Mansour M. S. M. (2016), A review on polycyclic aromatic hydrocarbons: Source, environmental impact, effect on human health and remediation. Elsevier Egyptian Journal of Petroleum. 25(1): 107123. DOI: $10.1016 /$ j.ejpe.2015.03.011

Alzieu C. (1999), Dredging and marine environment: state of the art. IFREMER. $225 \mathrm{p}$.

Ansari T.M., Marr I.L., Tariq N. (2004), Heavy Metals in Marine Pollution Perspective-A Mini Review. Journal of Applied Sciences, 4:1-20. DOI: 10.3923/jas.2004.1.20.

Bat L. (2014), Heavy metal pollution in the Black Sea. In: Düzgüneş, E., Öztürk, B., Zengin, M. (Eds.). Turkish Fisheries in the Black Sea. Published by Turkish Marine Research Foundation (TUDAV), 40: 71107, ISBN 987-975-8825-32-5

Boicenco L., Abaza V., Anton E., Bișinicu E., Buga L., Coatu V., Damir N., Diaconeasa D., Dumitrache C., Filimon A., Galațchi M., Golumbeanu M., Harcotă G., Lazăr L., Marin O., Mateescu R., Maximov V., Mihailov E., Nenciu M., Nicolaev S., Niță V., Oros A., Pantea E., Radu G., Spinu A., Stoica E., Tabarcea C., Timofte F, Țiganov G., Țoțoiu A, Vlas O., Vlăsceanu E., Zaharia T. (2018). Study on the elaboration of the report regarding the ecological status of the Black Sea marine ecosystem according to the requirements of Art. 17 - Strategy Framework Directive for the Marine Environment (2008/56/EC). 331 p (in Romanian).

Depledge M.H., Rainbow P.S. (1990), Models of regulation and accumulation of trace metals in marine invertebrates. Comp. Biochem. Physiol., 97(1): $1-7$.

García-Seoane R., Fernández J.A., Villares R., Aboal J.R. (2018), Use of macroalgae to biomonitor contaminants in coastal waters: Optimization of the methodology. ELSEVIER Ecological Indicators. 84: 710-726. DOI: 10.1016/j.ecolind.2017.09.015

Kilunga P.I., Sivalingam P., Laffite A., Grandjean D., Mulaji C.K., Alencastro L.F., Mpiana P.T., Poté J. (2017), Accumulation of toxic metals and organic micro-pollutants in sediments from tropical urban rivers, Kinshasa, Democratic Republic of the Congo, Chemosphere 179: 3748. 
Kissao G., Benjamin A., Musa B., Dimitri D. D., Magali P., Michael K., Wolfgang W. (2011), Polycyclic aromatic hydrocarbons and trace metal contamination of coastal sediment and biota from Togo, J. Environ. Monit., 13: 2033-2041. DOI: 10.1039/c1em10063g

Laane R.W. (1992), Background concentrations of natural compounds in rivers, seawater, atmosphere and mussels. International workshop on background concentrations of natural compounds, Haga. Report DGW - 92.033. ISBN 9036902126.

Marin O., Harcotă G., Gomoiu M. T. (2018), First macroalgae Pyropia leucosticta culture from the Romanian Black Sea coast performed under laboratory-controlled conditions. J Environ Prot Ecol, 19(3): 1138-1145.

Maroli L., Pavoni B., Sfriso A., Raccanelli S. (1993), Concentrations of polychlorinated biphenyls and pesticides in different species of macroalgae from the Venice Lagoon. Mar. Pollut. Bull. 26: 553-558.

Mayalen Z., Fabre M. S., Kerjean V., Deslandes E. (2009), Antioxidant and Cytotoxic Activities of Some Red Algae (Rhodophyta) from Brittany Coasts (France). Botanica Marina, 52: 268 - 277.

DOI: 10.1515/BOT.2009.037

Milchakova N. (2011), Marine Plants of the Black Sea. An Illustrated Field Guide. Digi Print Press, Sevastopol, 2011. 144 p. ISBN 978-966-025801-3.

Pavoni B., Caliceti M., Sperni L., Sfriso A. (2003), Organic micropollutants (PAHs, PCBs, pesticides) in seaweeds of the lagoon of Venice, Oceanologica Acta 26: 585-596. DOI: 10.1016/S03991784(03)00052-5

Redmond S., Green L., Yarish C., Kim J., Neefus C. (2014), New England Seaweed Culture Handbook-Nursery Systems. Connecticut Sea Grant CTSG-14-01. $92 \mathrm{p}$.

Syakti A.D., Asia L., Kanzari F., Umasangadji H., Malleret L., Ternois Y., Mille G., Doumenq P., (2013). Distribution of organochlorine pesticides (OCPs) and polychlorinated biphenyls (PCBs) in marine sediments directly exposed to wastewater from Cortiou, Marseille, Environ Sci Pollut Res, 19: 1524-1535. DOI 10.1007/s11356-011-0640-z

Tchounwou P. B., Yedjou C. G., Patlolla A. K., Sutton D. J. (2012), Heavy metal toxicity and the environment. Experientia supplementum, 101: 133-164. https://doi.org/10.1007/978-3-7643-8340-4_6 